\title{
EVALUATION OF [11C]MPC-6827 AS A MICROTUBULE TARGETING PET RADIOTRACER IN CANCER CELL LINES
}

\section{J. S. DILEEP KUMAR ${ }^{*}$, JAYA PRABHAKARAN ${ }^{1,2}$, NARESH DAMUKA ${ }^{3}$ JUSTIN W. HINES ${ }^{3}$, STEVEN J. KRIDEL ${ }^{4}$, J. JOHN MANN ${ }^{1,2,5}$, AKIVA MINTZ5, KIRAN KUMAR SOLINGAPURAM SAI ${ }^{3 *}$}

${ }_{1}^{1}$ Molecular Imaging and Neuropathology Division, New York State Psychiatric Institute, New York, 1051 Riverside Drive, New York, NY 10032, USA, 'Department of Psychiatry, Columbia University Medical Center, 1051 Riverside Drive, New York, NY 10032, USA,

${ }^{3}$ Department of Radiology, Wake Forest School of Medicine, One Medical Center Boulevard, Winston-Salem, NC 27157-1088, USA, ${ }^{4}$ Department of Cancer Biology, Wake Forest School of Medicine, One Medical Center Boulevard, Winston-Salem, NC 27157-1088, USA, 5Department of Radiology, Columbia University Medical Center, 622 West 168th Street, PB-1-301, New York, NY 10032, USA Email: dileep.kumar@nyspi.columbia.edu, ksolinga@wakehealth.edu

Received: 11 Sep 2019, Revised and Accepted: 19 Nov 2019

\section{ABSTRACT}

Objective: The objective of this study was to evaluate the uptake and specificity of $\left[{ }^{11} \mathrm{C}\right] \mathrm{MPC}-6827$, a MT targeted PET ligand in prostate, glioblastoma and breast cancer cells.

Methods: $\left[{ }^{11} \mathrm{C}\right] \mathrm{MPC}-6827$ was synthesized by reacting corresponding desmethyl precursors with $\left[{ }^{11} \mathrm{C}\right] \mathrm{CH}_{3} \mathrm{I}$ in a GE-FX2MeI/FX2M radiochemistry module. In vitro binding of $\left[{ }^{11} \mathrm{C}\right] \mathrm{MPC}-6827$ was performed in breast cancer MDA-MB-231, glioblastoma (GBM) patient-derived tumor (GBM-PDX), GBM U251 and prostate cancer $3(\mathrm{PC} 3)$ cell lines at $37^{\circ} \mathrm{C}$ in quadruplicate at 5, 15, 30, 60, and 90 minute incubation time. The nonspecific bindings were determined by incubation with unlabeled microtubule targeting agents MPC-6827, HD-800, colchicine, paclitaxel and docetaxel (5.0 $\mu$ M).

Results: $\left[{ }^{11} \mathrm{C}\right]$ MPC- 6827 provided the highest binding in the breast cancer cell, MDA-MB-231, among all the cells studied, with $90 \%$ specific binding. [11 C]MPC-6827 binds to glioblastoma PDX and U251 cells with 50\% and 40\% specific binding, whereas, prostate cancer cell line, PC3 cells showed $40 \%$ specific binding. $\left[{ }^{11} \mathrm{C}\right] \mathrm{MPC}-6827$ also exhibits binding to the taxane and colchicine binding sites of MTs, in MDA-MB-231 cells.

Conclusion: These data indicate that $\left[{ }^{11} \mathrm{C}\right] \mathrm{MPC}-6827 \mathrm{can}$ be a promising PET radiotracer for preclinical imaging of the brain and peripheral cancers.

Keywords: PET, Microtubule, Radiotracer, Cancer, Cytoskeleton

(C) 2020 The Authors. Published by Innovare Academic Sciences Pvt Ltd. This is an open-access article under the CC BY license (http://creativecommons.org/licenses/by/4.0/) DOI: http://dx.doi.org/10.22159/ijpps.2020v12i1.35657. Journal homepage: https://innovareacademics.in/journals/index.php/ijpps

\section{INTRODUCTION}

Microtubules (MTs) are one of the major components of cytoskeletal polymers, which are found in all eukaryotic cell. They are comprised of repeating, non-covalently bound $\alpha$, and $\beta$-tubulin heterodimers [1-4]. MTs serve as cellular conveyer belts that ferry vesicles, granules, and organelles like mitochondria, and chromosomes throughout the cell. Biochemical activities of MTs are regulated by free tubulin dimers, microtubule-stabilizing proteins (MSP), microtubule destabilizing or depolymerizing proteins, microtubule-associated proteins (MAP), and post-translational modification (PTM) of tubulin [5-8]. MTs also interact with intracellular transport proteins (e. g., kinesins and dyneins) and regulate tumor suppressor protein $\mathrm{p} 53$, and prosurvival proteins, such as Bcl-2 and survivin [9-11]. Correct alignment of the MT and mitotic spindle during cell division is crucial for cell fate determination, tissue organization, and normal development. Mutations associated with spindle disorientation through an increase in MT dynamics lead to an imbalance causing reduced or excessive cell proliferation that can result in cancer, birth disorders and brain diseases [12-17]. Altered tubulin isotype expression is the most widely characterized MT alteration reported in cancer [17]. Among these, $\beta$ isoform overexpression is a prognostic biomarker for poor overall survival in the majority of cancers and tumors, which is also correlated with drug resistance [18-22].

MTs have been among the most successful targets in anticancer therapy and therefore, a large number of microtubule targeting agents (MTAs) are in various stages of clinical development. Three classes of ligands (vinca alkaloids, paclitaxel derivatives and colchicine) are in market for the treatment of several malignancies and other disorders [23-26]. The application of these drugs has shown several limitations, however, such as neurological and bone marrow toxicity, and emergence of drug-resistant tumor cells due to the overproduction of multi-drug resistance-1 (MDR1), affinity to P- glycoprotein (p-GP) and breast cancer resistance protein (BCRP), and overexpression of different $\beta$-tubulins or tubulin mutations. To overcome these hurdles, several strategies are being developed to identify new MTAs as potential cancer therapeutics [27-32].

The successful radiotracers reported for MTs to date are $\left[{ }^{11} \mathrm{C}\right]$ paclitaxel, [ $\left.{ }^{18} \mathrm{~F}\right]$ fluoropaclitaxel and $\left[{ }^{11} \mathrm{C}\right]$ docetaxel [33]. Among this docetaxel and paclitaxel are well-characterized substrates of efflux transporters (p-GP, MDR1, BCRP), and therefore, the radiotracers do not show much uptake in the brain [33]. In this context, a screen of MTAs as positron emission tomography (PET) imaging agents found that $\left[{ }^{11} \mathrm{C}\right] \mathrm{MPC}-6827$ is the first successful brain penetrant PET tracer that exhibits high specific binding to MT in rodents [34]. Herein, we report the in vitro evaluation of $\left[{ }^{11} \mathrm{C}\right] \mathrm{MPC}-6827$ in triple-negative breast cancer MDA-MB-231, glioblastoma (GBM) patient-derived tumor (GBM-PDX), GBM U251 and prostate cancer-3 (PC3) cell lines.

\section{MATERIALS AND METHODS}

\section{Materials}

The commercial chemicals and solvents used in the synthesis were purchased from Sigma-Aldrich Chemical Co. (St. Louis, MO), Fisher Scientific Inc. (Springfield, NJ), or Lancaster (Windham, NH) and were used without further purification. MPC-6827, desmethyl-MPC6827 and $\left[{ }^{11} \mathrm{C}\right] \mathrm{MPC}-6827$ were synthesized as reported previously [34]. $\left.{ }^{[11} \mathrm{C}\right] \mathrm{CO}_{2}$ was produced from GE PET trace cyclotron. All the cancer cell lines were obtained from ATCC (VA, USA).

\section{Cell uptake experiments}

All the cell lines were cultured at $1 \times 10^{5}$ cells per 6 well (Corning, NY, USA) for $48 \mathrm{~h}$ in $5 \% \mathrm{CO}_{2}$ in $10 \%$ phosphate buffer culture medium (Gibco, Fishersci, VA). Three days before the uptake assays, aliquots of $2.5 \times 10^{4}$ cells suspended in culture media were added to each well 
of Costar 6-well plates to achieve the log growth phase with approximately $70 \%$ confluency at the time of the uptake assay. Additionally, the cells were incubated for an additional $24 \mathrm{~h}$ prior to the day of performing the cell assay. The blocking solution of MPC6827 [34], HD-800 [35], docetaxel, paclitaxel, and colchicine (Sigma Aldrich, MO) at a concentration of $5.0 \mu \mathrm{M}$ in the same culture media was freshly prepared on the same day of cell assay. All assays were performed in triplicate at $\mathrm{pH}$ 7.4. To demonstrate the blocking efficacy, all the blocker solutions were added to the corresponding blocking wells $30 \mathrm{~min}$ prior to the addition of the radiotracer. The assay buffer was formulated with radiotracer by adding $20 \mu \mathrm{l} / \mathrm{ml}$ of $\left[{ }^{11} \mathrm{C}\right] \mathrm{MPC}-6827$, at a concentration of $74 \mathrm{kBq} / \mathrm{ml}$ to each block and non-block condition. Three incubation times of 5, 15, 60 min were selected to demonstrate the baseline uptake and blocking for PC3, GBM-U251 and GBM-PDX cells, whereas, an additional 90-minute incubation was performed for MDA-MB-231 cells. The cell uptake assays were initiated by rinsing the cells with $2 \times 2 \mathrm{ml}$ of the phosphate buffer at room temperature [36-38]. Uptake was allowed to proceed for selected time periods and then rinsed with $1 \mathrm{ml}$ of the ice-cold buffer solution. Residual fluid was removed by pipette, and $200 \mu \mathrm{l}$ of $0.1 \%$ aqueous sodium dodecyl sulfate lysis buffer solution was added to each well. The plate was then agitated at room temperature and $1 \mathrm{ml}$ of the lysate was taken from each well for counting. Radioactivity was counted using the Wallac 1480 Wizard gamma counter (Perkin Elmer, Turku, Finland) [38]. Additional $20 \mu \mathrm{l}$ aliquots were taken in triplicate from each well for protein concentration determination using the Pierce bicinchoninic acid protein assay kit method (Rockford, IL). The uptake data in each sample from each well and the standard counts for each condition were expressed as counts per minute (cpm) of activity and was decay corrected for elapsed time. The cpm values of each well were normalized to the amount of radioactivity added to each well and the protein concentration in the well and expressed as percent uptake relative to the control condition [36-38]. The data were expressed as \%ID/mg of protein present in each well with $\mathrm{p}$ values $\leq .05$ considered statistically significant.

\section{RESULT AND DISCUSSION}

[11C]MPC-6827 was obtained in $40+5 \%$ yield at the end of synthesis (EOS) with a molar activity of $75+9.25 \mathrm{GBq} / \mu \mathrm{mol}$ and radiochemical purity $>99 \%$ (fig. 1) [34].<smiles>C[AlH]Oc1ccc(N(C)c2nc(C)nc3ccccc23)cc1</smiles>

Fig. 1: Chemical structure of [11C] MPC-6827

The uptake of $\left[{ }^{11} \mathrm{C}\right] \mathrm{MPC}-6827$ was first determined in prostate cancer PC3 cells [39]. The radioligand showed equilibrium binding after 60 -minute incubation and the highest uptake was found at 30minute incubation time with approximately $40 \%$ specific binding using $5 \mu \mathrm{mol}$ of unlabeled MPC-6827 as a blocking agent to test nonspecific binding (fig. 2).

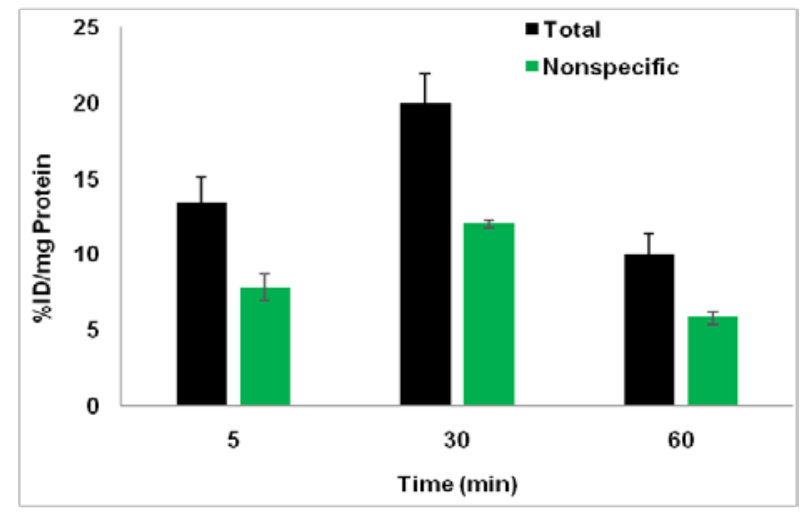

Fig. 2: Binding of $\left[{ }^{11} \mathrm{C}\right] M P C-6827$ in PC3 cells, values are reported as the mean \pm SD from three independent experiments

Subsequently, the binding of [11C]MPC-6827 was determined in GBM U251 and GBM-PDX cell lines. The radioligand showed uptake in both cells, however, the binding was lower than PC3 cells up to $30 \mathrm{~min}$ incubation time. However, the tracer exhibit higher uptake at the $60 \mathrm{~min}$ incubation time point than in PC3 cells. The uptake of $\left[{ }^{11} \mathrm{C}\right] \mathrm{MPC}-6827$ was partially blocked $(40 \%$ for GBM-U251 and 50\% for GBM-PDX) with unlabeled MPC-6827 (fig. 3 and 4).

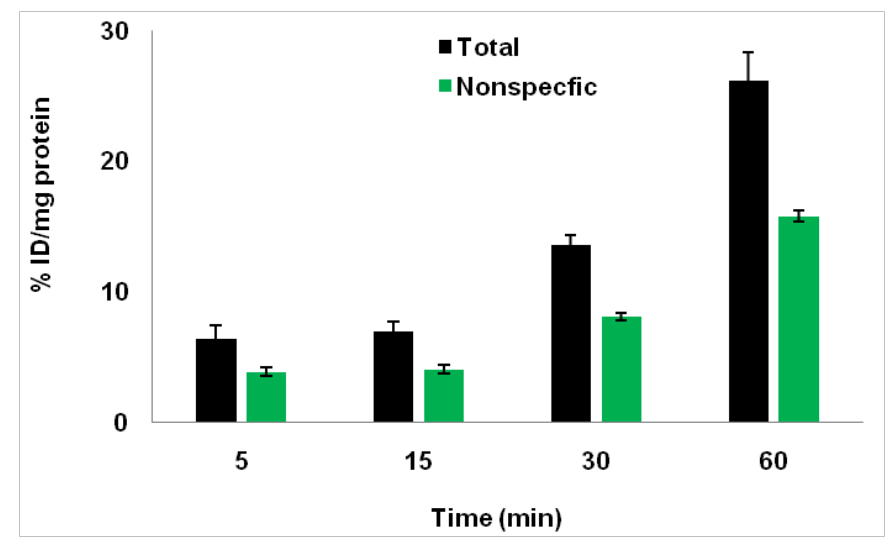

Fig. 3: Binding of $\left[{ }^{11} \mathrm{C}\right] M P C-6827$ in GBM-U251 cancer cells, values are reported as the mean \pm SD from three independent experiments 


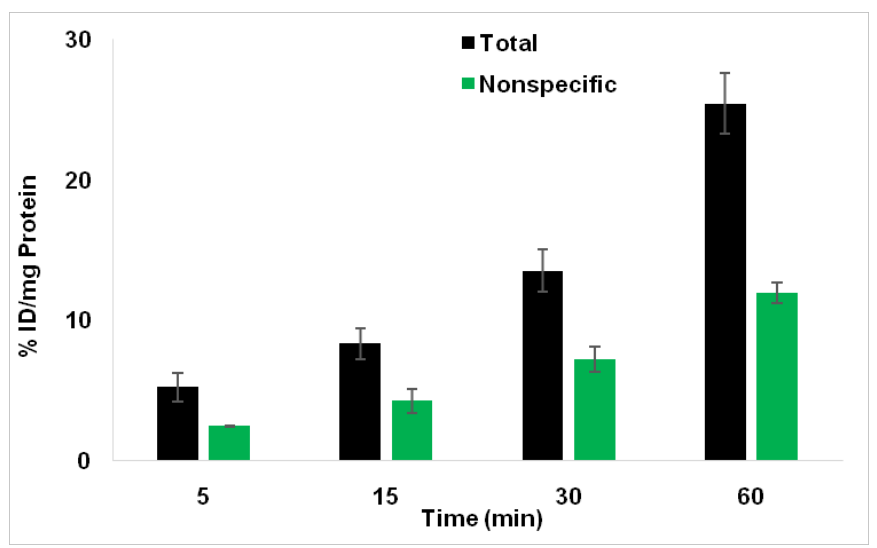

Fig. 4: Binding of [ $\left.{ }^{11} \mathrm{C}\right] \mathrm{MPC}-6827$ in GBM-PDX cancer cells, values are reported as the mean \pm SD from three independent experiments

40

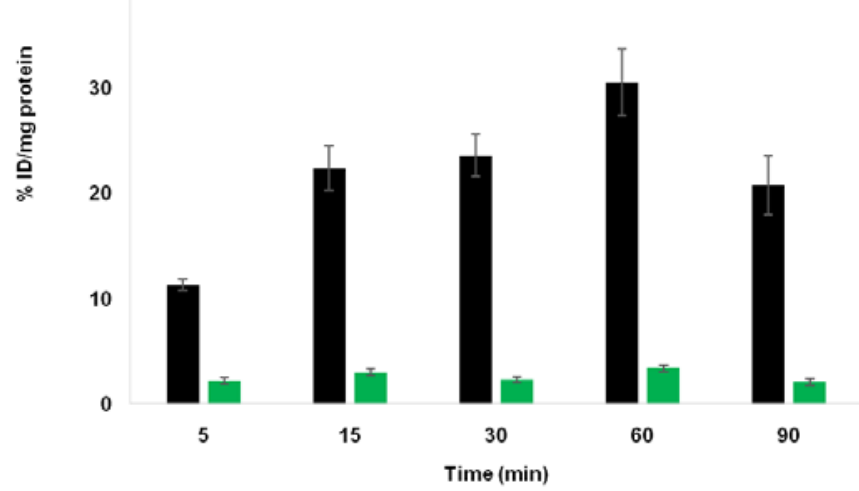

Fig. 5: Binding of [ $\left.{ }^{11} \mathrm{C}\right] \mathrm{MPC}-6827$ in MDA-MB-231 cancer cells, values are reported as the mean \pm SD from three independent experiments

Next, the binding of $\left[{ }^{11} \mathrm{C}\right] \mathrm{MPC}-6827$ was determined in MDA-MB-231 cells [40]. The radiotracer showed equilibrium binding at a 60 -minute incubation time point (fig. 5). Blocking with unlabeled ligand resulted in $90 \%$ specific binding. The radiotracer uptake and specific binding were highest in MDA-MB-231 cells compared to other tested cells. The differences in binding of radiotracer in these cells may be due to its variable expression of tubulin. After optimizing the equilibrium tracer uptake at $60 \mathrm{~min}$, we performed detailed blocking experiments with a series of MT ligands to determine the binding site of $\left[{ }^{11} \mathrm{C}\right] \mathrm{MPC}-6827$ in MDA-MB-231 cells. As is evident from these experiments, $\left[{ }^{11} \mathrm{C}\right] \mathrm{MPC}-$ 6827 showed $88 \%, 78 \%, 65 \%, 95 \%$, and $95 \%$ specific binding with 5 $\mu \mathrm{mol}$ each of docetaxel, paclitaxel, colchicine, MPC-6827 and structurally distinct MTA HD-800 [35], respectively. These results are consistent with the previous reports of photoaffinity and radioligand displacement studies showing MPC-6827 compete with paclitaxel and colchicine [41]. MPC-6827 and HD-800 show comparable specific binding in MDA-MB-231 cells. This effect was similar to our previous in vivo brain PET imaging experiments in mice with MPC-6827 and HD-800 indicating similar binding sites for these ligands with MTs [34, 35]. Although MPC-6827 and HD-800 are known to bind the colchicine site of MTs [34, 35, 41], colchicine blocks the least tubulin binding sites of $\left[{ }^{11} \mathrm{C}\right] \mathrm{MPC}-6827$, perhaps due to its low affinity to MT polymerization $\left(I C_{50}=3.2 \mu \mathrm{M}\right)[42]$. Among the taxanes, docetaxel showed higher blocking than paclitaxel.

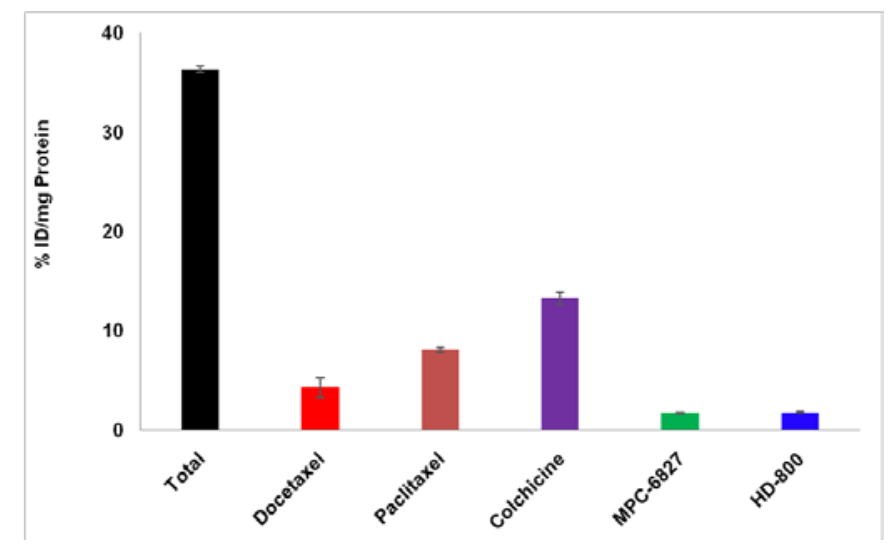

Fig. 6: Binding site determination of [ $\left.{ }^{11} \mathrm{C}\right] M P C-6827$ in MDA-MB-231 cancer cells. Values are reported as the mean \pm SD from three independent experiments 


\section{CONCLUSSION}

In summary, we have examined the cell uptake of $\left[{ }^{11} \mathrm{C}\right] \mathrm{MPC}-6827$ in prosteate, GBM and breast cancer cell lines. We found that $\left[{ }^{11} \mathrm{C}\right] \mathrm{MPC}-$ 6827 showed moderate specific binding in PC3, GBM-U251, and GBM-PDX cancer cells, whereas, robust specific binding was observed in breast cancer MDA-MB-231 cells with excellent specific binding. Moreover, cell uptake studies with MDA-MB-231 cells showed $\left[{ }^{11} \mathrm{C}\right] \mathrm{MPC}-6827$ binds to the taxane and colchicine binding sites of MTs. These results suggest that $\left.{ }^{[11} \mathrm{C}\right] \mathrm{MPC}-6827$ can be a radiotracer for preclinical PET imaging of central and peripheral cancers.

\section{ACKNOWLEDGEMENT}

This work was supported by CTSA WFSM TIP (UL1TR001420), P30 ADRC grant (5P30AG049638-03) and Diane Goldberg Foundation (NYSPI/CUMC).

\section{FUNDING}

Nil

\section{AUTHORS CONTRIBUTIONS}

JSDK and KKSS conceived the idea, prepared manuscript. JP, ND, JWH, SK, JJM, AM helped in analyzing the data, providing feedback on the manuscript.

\section{CONFLICT OF INTERESTS}

J John Mann receives royalties for commercial use of the C-SSRS from the Research Foundation of Mental Hygiene. All other authors delcare that no conflict of interest.

\section{REFERENCES}

1. Dubey J, Ratnakaran N, Koushika SP. Neurodegeneration and microtubule dynamics: death by a thousand cuts. Front Cell Neurosci 2015;9:343-57.

2. Janke C. The tubulin code: molecular components, readout mechanisms, and functions. J Cell Biol 2014;206:461-72.

3. Barlan K, Gelfand VI. Microtubule-based transport and the distribution, tethering, and organization of organelles. Cold Spring Harb Perspect Biol 2017;9:1-12.

4. Nogales E. Structural insights into microtubule function. Ann Rev Biochem 2010;69:277-302.

5. Forth S, Kapoor TM. The mechanics of microtubule networks in cell division. J Cell Biol 2017;216:1525-31.

6. Gadadhar S, Bodakuntla S, Natarajan K, Janke C. The tubulin code at a glance. J Cell Sci 2017;130:347-53.

7. Li L, Yang XJ. Tubulin acetylation: responsible enzymes, biological functions and human diseases. Cell Mol Life Sci 2015;72:4237-55

8. Song Y, Brady ST. Post-translational modifications of tubulin: pathways to functional diversity of microtubules. Trends Cell Biol 2015;25:125-36.

9. Scholey JM. Kinesin-2 motors transport IFT-particles, dyneins and tubulin subunits to the tips of caenorhabditis elegans sensory cilia: relevance to vision research? Vision Res 2012;75:44-52.

10. Rank KC, Rayment I. Functional asymmetry in kinesin and dynein dimers. Biol Cell 2013;105:1-13.

11. Mollinedo F, Gajate C. Microtubules, microtubule-interfering agents and apoptosis. Apoptosis 2003;8:413-50.

12. Varidaki A, Hong Y, Coffey ET. Repositioning microtubule stabilizing drugs for brain disorders. Front Cell Neurosci 2018;12:1-15.

13. Ballatore C, Brunden KR, Trojanowski JQ, Lee VM, Smith AB 3rd. Non-naturally occurring small molecule microtubulestabilizing agents: a potential tactic for cns-directed therapies. ACS Chem Neurosci 2017;8:5-7.

14. Pellegrini L, Wetzel A, Granno S, Heaton G, Harvey K. Back to the tubule: microtubule dynamics in parkinson's disease. Cell Mol Life Sci 2017;74:409-34.

15. Hur EM, Lee BD. Microtubule-targeting agents enter the central nervous system (CNS): double-edged swords for treating CNS injury and disease. Int Neurourol J 2014;18:171-8.
16. Eira J, Silva CS, Sousa MM, Liz MA. The cytoskeleton as a novel therapeutic target for old neurodegenerative disorders. Prog Neurobiol 2016;141:61-82.

17. Brunden KR, Lee VM, Smith AB, Trojanowski JQ, Ballatore C. Altered microtubule dynamics in neurodegenerative disease therapeutic potential of microtubule-stabilizing drugs. Neurobiol Dis 2017;105:328-35.

18. Katsetos CD, Draber P. Tubulins as therapeutic targets in cancer: from bench to bedside. Curr Pharm Des 2012;18:277892.

19. Katsetos CD, Draber P, Kavallaris M. Targeting BIII-tubulin in glioblastoma multiforme: from cell biology and histopathology to cancer therapeutics. Anticancer Agents Med Chem 2011;11:719-28.

20. Laggner U, Pipp I, Budka H, Hainfellner JA, Preusser M. Immunohistochemical detection of class III beta-tubulin in primary brain tumours: variable expression in most tumour types limits utility as a differential diagnostic marker. Histopathology 2007;50:949-52.

21. Miconi G, Palumbo P, Dehcordi SR, La Torre C, Lombardi F, Evtoski Z, et al. Immunophenotypic characterization of human glioblastoma stem cells: correlation with clinical outcome. J Cell Biochem 2015;116:864-76.

22. Bordji K, Grandval A, Cuhna Alves L, Lechapt Zalcman E, Bernaudin M. Hypoxia-inducible factor- $2 \alpha$ (HIF-2 $\alpha$ ), but not HIF- $1 \alpha$, is essential for hypoxic induction of class III $\beta$-tubulin expression in human glioblastoma cells. FEBS J 2014;281:5220-36.

23. Mukhtar E, Adhami VM, Mukhtar H. Targeting microtubules by natural agents for cancer therapy. Mol Cancer Ther 2014;13:275-84

24. Florian S, Mitchison TJ. Anti-microtubule drugs. Methods Mol Biol 2016;1413:403-21.

25. Wilson L, Jordan MA. New microtubule/tubulin-targeted anticancer drugs and novel chemotherapeutic strategies. J Chemother 2004;16:83-5.

26. Dostal V, Libusova L. Microtubule drugs: action, selectivity, and resistance across the kingdoms of life. Protoplasma 2014;251:991-1005.

27. Karki R, Mariani M, Andreoli M, He S, Scambia G, Shahabi S, et al. ßIII-tubulin: biomarker of taxane resistance or drug target? Expert Opin Ther Targets 2013;17:461-72.

28. Bukhari SNA, Kumar GB, Revankar HM, Qin HL. Development of combretastatins as potent tubulin polymerization inhibitors. Bioorg Chem 2017;72:130-47.

29. Sarkar T. Microtubule targeting anti-mitotic agents as anticancer drugs: a review. Int J Multidisciplinary Approach Studies $2015 ; 10: 187-94$

30. Zhao Y, Mu X, Du G. Microtubule-stabilizing agents: new drug discovery and cancer therapy. Pharmacol Ther 2016;162:13443.

31. Cortes J, Vidal M. Beyond taxanes: the next generation of microtubule-targeting agents. Breast Cancer Res Treat 2012;133:821-30.

32. Tangutur AD, Kumar D, Krishna KV, Kantevari S. Microtubule targeting agents as cancer chemotherapeutics: an overview of molecular hybrids as stabilizing and destabilizing agents. Curr Top Med Chem 2017;17:2523-37.

33. van der Veldt AA, Hendrikse NH, Smit EF, Mooijer MP, Rijnders $\mathrm{AY}$, Gerritsen WR, et al. Biodistribution and radiation dosimetry of 11C-labelled docetaxel in cancer patients. Eur J Nucl Med Mol Imaging 2010;37:1950-8.

34. Kumar JSD, Solingapuram Sai KK, Prabhakaran J, Dileep H, Mintz A, Mann JJ. Radiosynthesis and In vivo evaluation of $\left[{ }^{11} \mathrm{C}\right] \mathrm{MPC}-6827$, the first brain penetrant microtubule PET ligand. J Med Chem 2018;61:2118-23.

35. Solingapuram Sai KK, Prabhakaran J, Ramanathan G, Rideout S, Whitlow C, Mintz A, et al. Radiosynthesis and evaluation of $\left[{ }^{11} \mathrm{C}\right] \mathrm{HD}-800$, a high affinity brain penetrant PET tracer for imaging microtubules. ACS Med Chem Lett 2018;9:452-6.

36. Solingapuram Sai KK, Sattiraju A, Almaguel FG, Xuan A, Rideout S, Krishnaswamy. Peptide-based PET imaging of the tumor restricted IL13RA2 biomarker. Oncotarget 2017;8:509971007. 
37. Solingapuram Sai KK, Bashetti N, Chen X, Norman S, Hines JW, Meka O, et al. Initial biological evaluations of F-KS1, a novel ascorbate derivative to image oxidative stress in cancer. EJNMMI Res 2019;9:43-52.

38. Solingapuram Sai KK, Das BC, Sattiraju A, Almaguel FG, Craft S, Mintz A. Radiolabeling and initial biological evaluation of [F]KBM-1 for imaging RAR- $\alpha$ receptors in neuroblastoma. Bioorg Med Chem lett 2017;27:1425-7.

39. Inbathamizh L, Padmini E. Evaluation of growth inhibitory potential of moringa oleifera flowers on pc3 cell lines. Asian J Pharm Clin Res 2013;6:60-4.
40. Balashanmugam P, Mosa CK, Kowsalya E. In vitro cytotoxicity and antioxidant evaluation of biogenic synthesized gold nanoparticles from marsilea quadrifolia on lung and ovarian cancer cells. Int J Appl Pharm 2018;10:153-8.

41. Kasibhatla S, Baichwal V, Cai SX, Roth B, Skvortsova I, Skvortsov S, et al. MPC-6827: a small-molecule inhibitor of microtubule formation that is not a substrate for multidrug resistance pumps. Cancer Res 2007;67:5865-71.

42. De Martino G, La Regina G, Coluccia A, Edler MC, Barbera MC, Brancale A, et al. Arylthioindoles, potent inhibitors of tubulin polymerization. J Med Chem 2004;4725:6120-3. 